\title{
Characteristics of ASTM A36 steel plate corrosion rate due to bending treatment with angle, corrosion media, and corrosion time variations
}

\author{
Muhamad Zainal Arifin ${ }^{1 *}$, Djoko Kustono ${ }^{1}$, Widiyanti $^{1}$ \\ ${ }^{1}$ Department of Mechanical Engineering, Faculty of Engineering, Universitas Negeri Malang, 65145 Malang, Indonesia \\ *E-mail: zainal12362@gmail.com \\ * corresponding author
}

ABSTRACT

Bending can cause stress to the workpiece, where the stress can cause a fine crack in the metal which can lead to corrosion. Corrosion that occurs can result in a decline in the quality of metals, especially in mechanical properties. This study aims to determine the characteristics of the corrosion rate of each bending angle. This study uses low carbon steel with ASTM A36 type plates, this type of steel is often used in ship production. This research is an experimental study using descriptive statistical methods, and 3x3 factorial Anava for testing hypotheses. From this research, the results obtained in the form of corrosion rate values, where the characteristics of the corrosion rate of steel plates with the lowest corrosion resistance are at $60^{\circ}$ bending treatment, seawater media, and 48 hours with a corrosion rate of $2.005 \mathrm{mmpy}$. Corrosion rate characteristics with the best resistance are in the bending treatment of $120^{\circ}$, PDAM water media, and 24 hour time with a corrosion rate of $0.695 \mathrm{mmpy}$. Hypothesis test results state that there is a significant effect of variations in bending angle, corrosion media, and corrosion time on the value of the corrosion rate.
ARTICLE INFO

\author{
Article history \\ Received: \\ 4 May 2020 \\ Revised: \\ 14 October 2020 \\ Accepted: \\ 14 October 2020 \\ Keywords \\ Corrosion, \\ Corrosion, Bending, \\ ASTM A36
}

Corrosion Rate, Stress

This is an open access article under the CC-BY-SA license.

\section{Introduction}

Bending is widely applied to the manufacturing industry, especially in the manufacture of machine bodies, engine covers, brackets, truck bodies, and another. In the process of bending can result in stress on the workpiece, where the stress can result in fine cracking of metals that can trigger corrosion. Corrosion that occurs can result in a decline in metal quality. The decline in quality is certainly something to consider in the bending process, and therefore it is necessary to test the corrosion rate of the bending plate.Quality degradation in question is the decline in mechanical properties of metals. 
Journal of Engineering and Applied Technology

Vol. 1, No. 2, March 2020, pp. 1-10

Decreased mechanical properties caused by corrosion include; decreased steel strength, steel tenacity, and steel toughness. Mechanical properties are very important in the planning of a metal product, especially that the products resulting from bending of the plate (fold) are machined products, which require planning and maintenance, so that the loss of corrosion caused by bending becomes a consideration in plate Works

\section{Method}

This study uses an experimental method with a one shot case study model, where specimens are given certain treatments, then the results are observed. Data analysis techniques used in this study were descriptive statistics and $3 \times 3$ factorial anova statistical. Descriptive statistics are used to discuss the characteristics of the corrosion rate, while $3 \times 3$ factorial inferential statistics are used to test the research hypothesis.

The material used in this research is ASTM A36 low carbon steel plate with a thickness of 4.8 $\mathrm{mm}$. Before bending, the specimen is cut to size $20 \mathrm{~mm}$ x $50 \mathrm{~mm}$ by 90 pieces. Specimens with bending treatment amounted to 81 , with a bending angle of $60^{\circ}, 90^{\circ}$ and $120^{\circ}$, so that each bend angle was 27 specimens. The remaining plates are without bending treatment which amounts to 9 .

This research focuses on stress corrosion, but in the bending process there are parts of the plate that are affected by stress, and some are not affected by stress. The part that is affected by the stress is the center of the plate with a size of $25 \mathrm{~mm} \times 20 \mathrm{~mm}$, while the part that is not affected by the voltage is the two ends of the plate with a size of $12.5 \times 20 \mathrm{~mm}$, the part has the same dimensions or can be called $1 / 2$ the part that is affected by the stress.

So that the results of corrosion testing carried out purely by stress corrosion require a plate without bending treatment which is then the weight of $1 / 2$ plate of the corrosion rate test results are used to reduce the weight of $1 / 2$ plate by bending treatment. The weight reduction is carried out at the initial weighing, and at the end of the specimen. Weighing the specimens in this study using a digital scale with a precision of $0.001 \mathrm{gr}$.

The corrosion rate testing standard used in this study is ASTM G31-72 Standard Practice for Laboratory Immersion Corrosion Testing of Metals. Fig. 1 is an illustration of the bending process with the part of the plate being affected and not affected by stress.

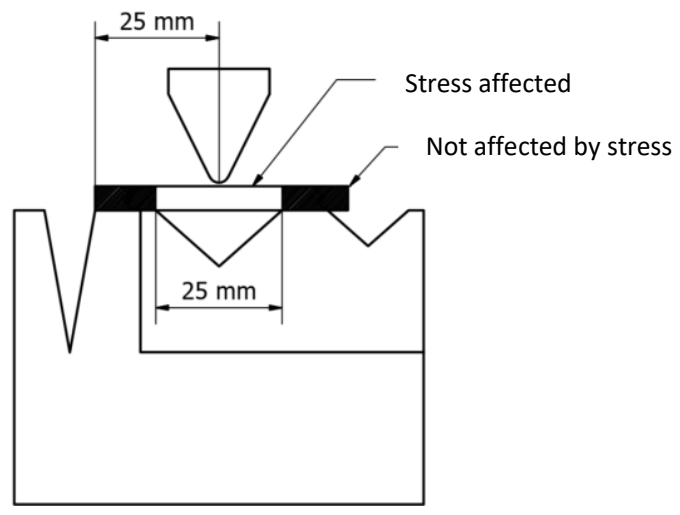

Fig. 1. Plate section 
Journal of Engineering and Applied Technology

Vol. 1, No. 2, March 2020, pp. 1-10

Corrosion media used are PDAM Malang City water, Malang City rainwater, and Sendang Biru Regency Malang sea water. Rainwater media, and PDAM water are taken directly with each volume of 19L, specifically for sea water media taken at a distance of about $1 \mathrm{~km}$ from the beach so that the sea water used is not contaminated with fresh water. The volume of the corrosion media can be calculated using the formula based on the following ASTM G31-72 standard.

Liquid volume $=($ Minimum ratio $) \times($ Surface area $)$

Information:

Minimum ratio $=0.20-0.40\left(\mathrm{ml} / \mathrm{mm}^{2}\right)$

Surface area $=2 \times(\mathrm{p} \times 1+\mathrm{p} \times \mathrm{t}+1 \times \mathrm{t})\left(\mathrm{mm}^{2}\right)$

Thus the minimum volume of fluid that can be used is

$$
\begin{aligned}
\text { Liquid volume } & =0.20 \times[2 \times(50 \times 20+50 \times 4.8+20 \times 4.8) \\
& =0.20 \times 2672 \\
& =534 \mathrm{ml}
\end{aligned}
$$

Corrosion rate testing method used is a weight loss method, this method is often used because the equipment used is simple, and the test results are accurate. Corrosion time variations used in this study were 24 hours, 48 hours and 72 hours. Based on ASTM G31-72 the minimum time to check corrosion rate is 48 hours, but because the material used is classified as susceptible to corrosion, the lowest variation used is 24 hours. The formula used to calculate the corrosion rate is as follows.

$$
\text { Corrosion rate }=\frac{\mathrm{K} \cdot \mathrm{w}}{\rho \cdot \mathrm{A} \cdot \mathrm{T}}
$$

Information:

$\mathrm{K}=$ Constants in mmpy $\left(8.76 \times 10^{4}\right)$

$\mathrm{W} \quad=$ Weight loss $(\mathrm{mg})$

$\boldsymbol{\rho} \quad=$ Density $\left(\mathrm{mg} / \mathrm{mm}^{3}\right)$

A $\quad=$ Surface area $\left(\mathrm{mm}^{2}\right)$

$\mathrm{T} \quad=$ Corrosion time (hours)

\section{Results and Discussion}

Corrosion rate testing is carried out for the part that is affected by the stress that is the middle part of the plate with a size of $20 \mathrm{~mm}$ x $25 \mathrm{~mm} \times 4.8 \mathrm{~mm}$. The results of this study are the corrosion rate values of each treatment. Treatments with time variations (A), bending angles (B), and corrosion media (C). Table 1 shows the presentation of the data of ASTM A36 steel plate corrosion test results. 
Journal of Engineering and Applied Technology

Vol. 1, No. 2, March 2020, pp. 1-10

Table 1. Corrosion rate value (mmpy)

\begin{tabular}{|c|c|c|c|c|c|}
\hline \multirow{2}{*}{ No } & \multirow{2}{*}{ Time } & \multirow{2}{*}{ Angle } & \multicolumn{3}{|c|}{ Corrosion Media } \\
\hline & & & PDAM & Rain water & Sea water \\
\hline \multirow{10}{*}{1} & \multirow{3}{*}{24} & 60 & 1.444 & 2.406 & 0.962 \\
\hline & & 90 & 1.444 & 2.085 & 0.962 \\
\hline & & 120 & 1.444 & 1.764 & 0.962 \\
\hline & \multirow{3}{*}{48} & 60 & 1.444 & 1.604 & 1.845 \\
\hline & & 90 & 1.444 & 1.444 & 1.845 \\
\hline & & 120 & 1.764 & 1.283 & 1.363 \\
\hline & \multirow{3}{*}{72} & 60 & 1.39 & 1.497 & 1.978 \\
\hline & & 90 & 1.497 & 1.176 & 1.23 \\
\hline & & 120 & 1.176 & 0.749 & 1.123 \\
\hline & \multirow{3}{*}{24} & 60 & 1.123 & 1.764 & 1.283 \\
\hline \multirow{8}{*}{2} & & 90 & 0.481 & 0.802 & 1.283 \\
\hline & & 120 & 0.481 & 1.123 & 1.283 \\
\hline & \multirow{3}{*}{48} & 60 & 1.764 & 1.283 & 2.326 \\
\hline & & 90 & 1.764 & 1.604 & 1.684 \\
\hline & & 120 & 1.604 & 1.604 & 1.524 \\
\hline & \multirow{3}{*}{72} & 60 & 1.176 & 1.925 & 1.764 \\
\hline & & 90 & 1.069 & 1.497 & 1.337 \\
\hline & & 120 & 1.069 & 1.283 & 0.802 \\
\hline \multirow{9}{*}{3} & \multirow{3}{*}{24} & 60 & 0.802 & 0.481 & 1.283 \\
\hline & & 90 & 0.481 & 0.16 & 0.962 \\
\hline & & 120 & 0.16 & 0.16 & 0.962 \\
\hline & \multirow{3}{*}{48} & 60 & 1.123 & 2.567 & 1.845 \\
\hline & & 90 & 0.802 & 1.764 & 1.845 \\
\hline & & 120 & 0.642 & 1.123 & 1.845 \\
\hline & \multirow{3}{*}{72} & 60 & 1.497 & 1.283 & 1.551 \\
\hline & & 90 & 0.642 & 1.069 & 1.337 \\
\hline & & 120 & 0.856 & 0.856 & 0.588 \\
\hline
\end{tabular}

\subsection{Characteristics of Corrosion Rate Due to Bending $60^{\circ}$}

Stresses that occur due to bending $60^{\circ}, 90^{\circ}$ and $120^{\circ}$ are certainly different, this is evidenced by using Autodesk Inventor 2017 software, this simulation is in the form of stress analysis in order to determine the stress distribution caused by the bending process. In this simulation each is given the same load that is $100 \mathrm{~N}$ on bending $60^{\circ}, 90^{\circ}$, and $120^{\circ}$.

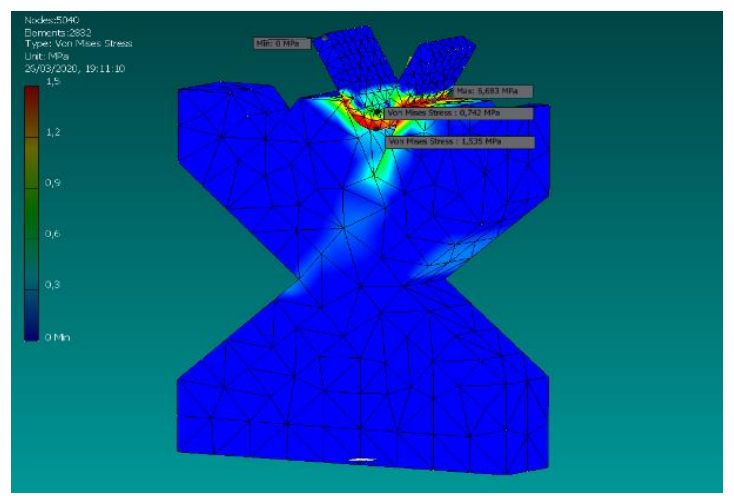

Fig. 2. Stress distribution bending $60^{\circ}$ 
The stress that occurs in bending $60^{\circ}$ is the biggest compared to the others. The part that is affected by the maximum stress is red area, and the neutral stress is blue area. The maximum stress that occurs is $6.683 \mathrm{MPa}$. As a result of this bending treatment the thickness of the plate in the middle is reduced by $0.7 \mathrm{~mm}$.

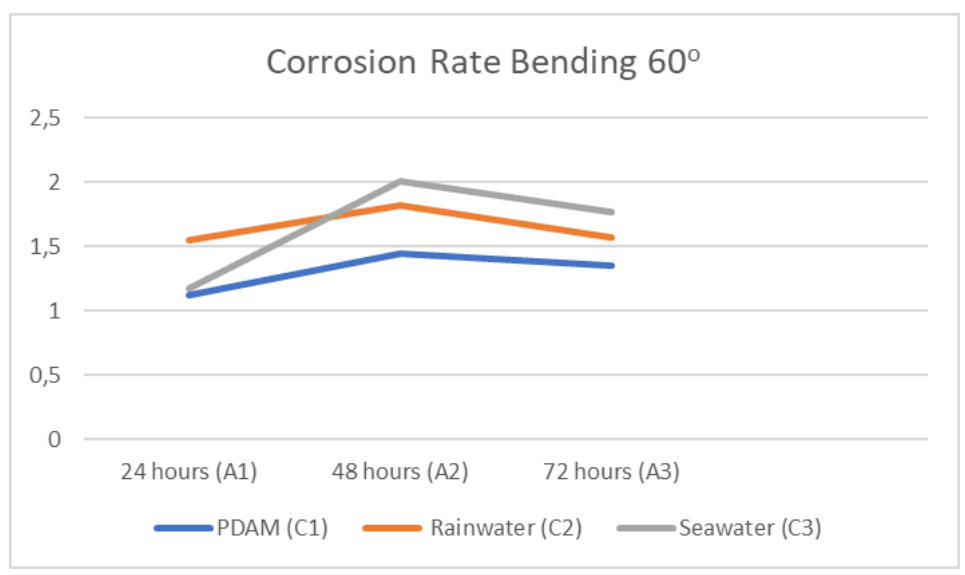

Fig. 3. Bending $60^{\circ}$ corrosion rate chart

The characteristics of ASTM A36 steel plate corrosion rate due to bending $60^{\circ}$ can be seen in the Fig. 3. At 24 hours the rainwater media was the most corrosive, but at 48 hours the sea water media became the most corrosive. The lowest corrosion rate value is at $\mathrm{A}_{1} \mathrm{C}_{1}$ treatment ( 24 hour time, and PDAM water media), the highest corrosion rate value is at $\mathrm{A}_{2} \mathrm{C}_{3}$ treatment (48 hour time, and seawater media). The quality of the corrosion resistance is classified as poor.

\subsection{Characteristics of Corrosion Rate Due to Bending $90^{\circ}$}

Maximum stress that occurs due to bending $90^{\circ}$ is in the middle of the plate with a value of $5.742 \mathrm{MPa}$, while the part that is not affected by the stress is the blue area. For more details, the stress distribution can be seen in Fig. 4 below.

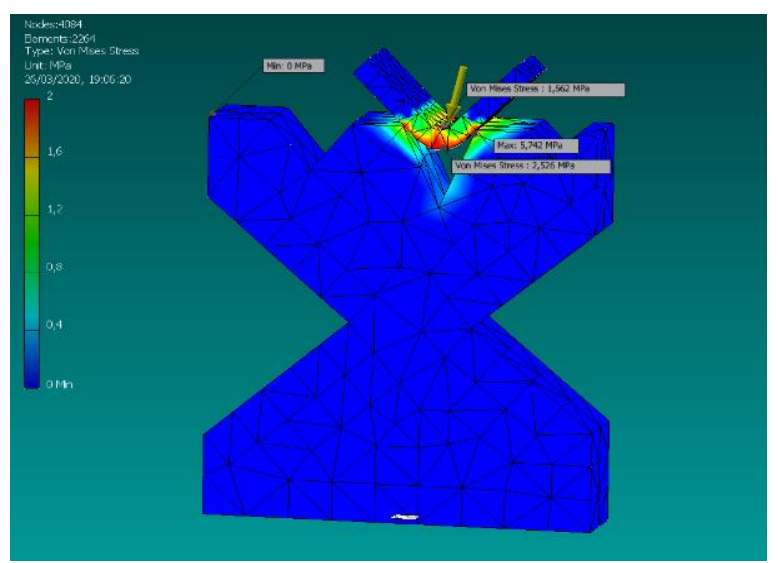

Fig. 4. Stress Distribution Bending $90^{\circ}$ 
Journal of Engineering and Applied Technology

Vol. 1, No. 2, March 2020, pp. 1-10

As a result of bending $90^{\circ}$ plate thickness is reduced by $0.4 \mathrm{~mm}$ in the middle. Just like the previous stress analysis simulation using Autodesk Inventor 2017 software, with a load of 100N. The characteristics of ASTM A36 steel plate corrosion rate due to bending $90^{\circ}$ lower than with bending $60^{\circ}$ that is because the stress that occurs is smaller. The greater the bending angle, the smaller the stress that occurs. The characteristics of the corrosion rate due to bending $90^{\circ}$ can be seen in Fig. 5 below.

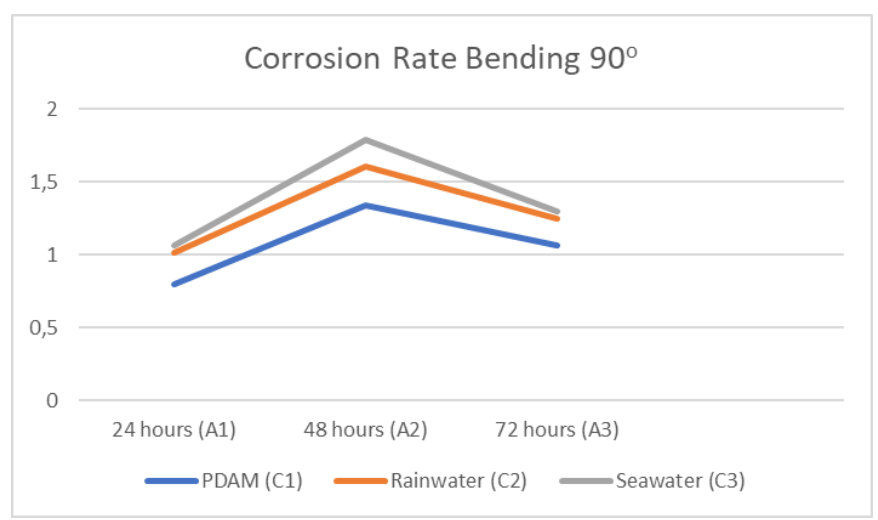

Fig. 5. Bending $90^{\circ}$ Corrosion Rate Chart

Corrosion rate tends to increase at 48 hours, then decrease at 72 hours. The most corrosive media are sea water with a $\mathrm{pH}$ of 7.3, then rainwater with a $\mathrm{pH}$ of 6.4, and PDAM water with a $\mathrm{pH}$ of 6.2. The highest corrosion rate is in the $\mathrm{A}_{2} \mathrm{C}_{3}$ treatment (48 hours, and seawater media) with poor corrosion resistance. Corrosion rate with the lowest value is at $\mathrm{A}_{1} \mathrm{C}_{1}$ treatment ( 24 hours, and PDAM water media) with fair corrosion resistance.

\subsection{Characteristics of Corrosion Rate Due to Bending $120^{\circ}$}

The stress that occurs due to bending $120^{\circ}$ is the smallest compared to other angular variations. The maximum stress that occurs is in the red area, which is in the middle of the plate with a value of 4.453 MPa. The part that is blue is the part of the plate that is not affected by stress.

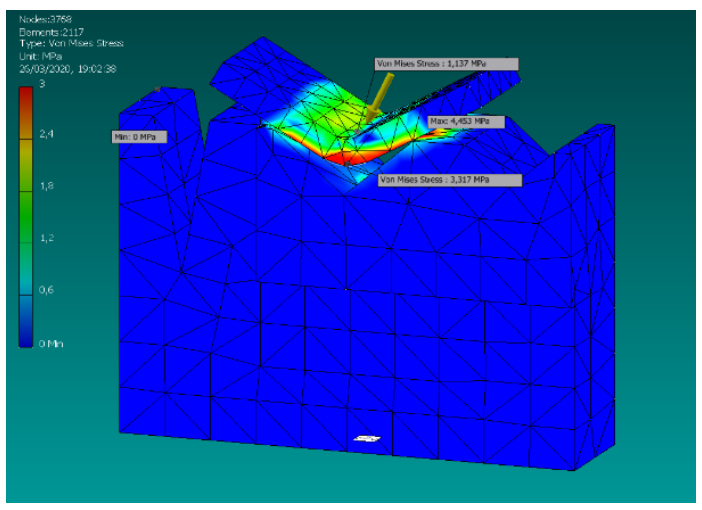

Fig. 6. Stress Distribution Bending $120^{\circ}$ 
Journal of Engineering and Applied Technology

Vol. 1, No. 2, March 2020, pp. 1-10

In the stress analysis simulation the same as before, namely by using a load of $100 \mathrm{~N}$. The bending treatment with an angle of $120^{\circ}$ causes the thickness of the center of the plate to be reduced by 0.2 $\mathrm{mm}$, so that the thickness of the plate becomes $4.6 \mathrm{~mm}$.

Corrosion rate characteristic of $120^{\circ}$ bending is the best corrosion resistance compared to other angular variations, it is because the stress (corrosion trigger) at $120^{\circ}$ bending is relatively low. The greater bending angle that is formed, the smaller the stress that occurs. Here is Fig. 7 on the chart of ASTM A36 steel plate corrosion rate due to bending $120^{\circ}$.

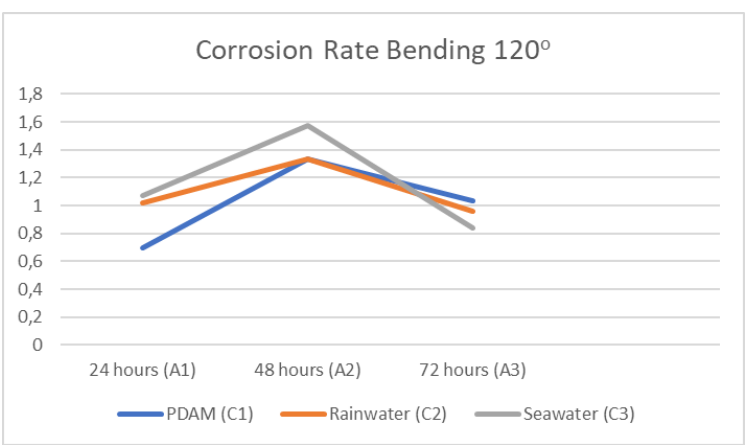

Fig. 7. Bending $120^{\circ}$ Corrosion Rate Chart

Corrosion rate with the greatest value is in the $\mathrm{A}_{2} \mathrm{C}_{3}$ treatment (48 hours, and seawater media) with poor corrosion resistance. Corrosion rate with the lowest value is at $\mathrm{A}_{1} \mathrm{C}_{1}$ treatment ( 24 hour time, and PDAM water media) with fair corrosion resistance. Classification of the corrosion rate is based on ASTM G31-72 standard, where if the corrosion rate value of 1-5 mmpy is classified as poor, and 0.5-1 mmpy is classified as fair.

From the whole test it is proven that the bending angle with the best corrosion resistance is $120^{\circ}$, and the bending angle with the worst corrosion resistance is $60^{\circ}$. This is due to the stresses that occur due to bending, the greater the stresses resulting in rapid corrosion rates. The results of hypothesis testing also stated that there was a significant effect of variations in bending angle, corrosion media, and corrosion time on the corrosion rate values.

\section{Conclusion}

The results of ASTM A36 steel plate corrosion rate due to bending with variations in angle, corrosion media, and corrosion time prove that there is an influence of the three variations on the value of corrosion rate. The smaller of bending angle causes the faster corrosion rate, it is because the small bending angle causes a large stress in the bending process.

Sea water corrosion media is the most corrosive, it is due to the large $\mathrm{pH}$ of sea water. The $\mathrm{pH}$ of sea water is 7.3, while the $\mathrm{pH}$ of rainwater is 6.4, and the $\mathrm{pH}$ of PDAM water is 6.2. This research proves that the greater the $\mathrm{pH}$ value of the corrosion media, the higher the corrosion rate can be.

Corrosion time also affects the corrosion rate value, the corrosion time with the highest corrosion rate value of all tests is 48 hours, and the corrosion time with the lowest corrosion rate value is 24 hours. The results of hypothesis testing also state that there is a significant effect of variations in bending angle, corrosion media, and corrosion time on the corrosion rate values. 
Journal of Engineering and Applied Technology

Vol. 1, No. 2, March 2020, pp. 1-10

\section{References}

[1] Ambiyar. Teknik Pembentukan Pelat Jilid 3. Jakarta: Direktorat Pembinaan Sekolah Menengah Kejuruan. 2008.

[2] Andarany, K.S.. "Studi Karakterisasi Laju Korosi Logam Aluminium Dan Pelapisan Dengan Menggunakan Membran Sellulosa Asetat”. Jurnal Teknik Mesin (JTM). Vol. 06. 2017

[3] A, K.Mangla., Vikas, C., \& Gurbhinder, S. "High Temperature Corrosion And Its Control In Coal Fired Boilers". International Journal of Latest Trends in Engineering and Technology. ISSN: 2278-621X. 2017.

[4] ASTM.A36. 2004. Standard Spesification of Carbon Structural Steel. New York: American.

[5] ASTM G31-72. 2004. Standard Practice for Laboratory Immersion Corrosion Testing of Metals. New York: American.

[6] Callister, W.D. 2007. Material Science and Engineering An Introduction. New York: John Wiley and Sons, Inc.

[7] Chinwko, E.C., Odio, B.O., Chukwuneke, J.L., \& Sinebe J. E. "Investigation Of The Effect Of Corrosion On Mild Steel In Five Different Environments". International Journal of Scientic and Technology Research Vol. 3 Issue: 7. ISSN 2277-8616. 2014.

[8] Dewi, H., \& Athanasius, P.B. "Analisis Retakan Korosi Tegangan Pada Aluminium Dengan Variasi Pembebanan Dalam Media Korosi Hcl 1m”. Jurnal Teknik Mesin S-1. 2014.

[9] Fajar, M.S., Sri, W., \& Nani, M. "Pengaruh Penambahan Inhibitor Ekstrak Kulit Manggis (Garcinia Mangostana L) Terhadap Laju Korosi Pada Pipa Pendingin”. Jurnal Mer-C. No.2 Vol.1. 2018.

[10] Kana, S.I., \& M, Dalil. "Pengaruh Pembengkokan Terhadap Kekuatan Baja Struktur Tulangan Beton Di Lingkungan Air Gambut”. Jom FTEKNIK Volume 2. 2015.

[11] Mustafa, O., Hakan, G. "Microstructural Characterization and Deformation of X10CrAlSi24 Sheet Material Applied V-Bending Process". Technical Gazette. ISSN 1848-6339.

[12] Nendi, S., Darmawan, H., Liu, K., \& Setianto. “Analisis Korosi Pipa Baja Karbon Api 51-X65 Dengan Metoda Pembebanan Tiga Titik Pada Lingkungan Gas H2s Dan Co2 Jenuh Di Dalam Larutan Asam Asetat". Jurnal Ilmu dan Inovasi Fisika. 2018.

[13] Nendi, S., Sri, S., Otong, N., \& Febi, L. "Analisa Tegangan Pada Pipa Baja Karbon API 5LGradeB Terhadap Laju Korosi Dalam Larutan $\mathrm{NaCl}$ dan Asam Asetat". Jurnal Fisika Indonesia. No.55. 2015.

[14] Purnama, W.E. 2015. Analisa Sifat Mekanik Dan Laju Korosi Hasil Pengelasan SMAW Pada Baja ST 41 Dengan Variasi Jenis Elektroda Akibat Pengkorosian Oleh Air Laut. Skripsi tidak diterbitkan. Malang: FT UM.

[15] Riki, N., \& Arya, M.S. 2016. Analisis Laju Korosi Erosi Pada Baja St60 Dalam Berbagai Medium Air Laut. Jurnal Teknik Mesin Vol. 4 No:3.Dari.https://jurnalmahasiswa.unesa.ac.id/ index .php/jtm.unesa/article/view.

[16] Sudjimat, D.A. Pengantar Metodologi Penelitian. Malang: Universitas Negeri Malang. 2010.

[17] Sri, W. Karat dan Pencegahanya. Jakarta: PT. Pradnya Paramita. 2001.

[18] Sucipto, R.L. Analisa Astm A36 Akibat Pengaruh Suhu Dan Quenching Terhadap Nilai Ketanguhannya. Thesis. Surabaya: ITS. 2016.

[19] Sugiyono. Metode Penelitian Kuantitatif Kualitatif Dan R\&D. Bandung: Alfabeta. 2014. 
Journal of Engineering and Applied Technology

Vol. 1, No. 2, March 2020, pp. 1-10

[20] Sundjono., Gadang, p., Lutviasari, N., \& Siska, P. "Corrosion Behavior of Mild Steel in Seawater from Northern Coast of Java and Southern Coast of Bali, Indonesia". J. Eng. Technology. Sci., Vol. 49, No. 6. ISSN: 2337-5779. 2017.

[21] Syamsul, H. Teknologi Bahan. Yogyakarta: CV Andi Offset (anggota IKAPI). 2016.

[22] Syamsul, H. Teknologi Bahan Lanjut. Yogyakarta: ANDI (anggota IKAPI). 2018.

[23] Tegar, S.P. Perbedaan Laju dan Bentuk Korosi Pada Baja Electrolitic Thin Plate (ETP) Dengan dan Tanpa Goresan Pada Lapisan. Thesis. Malang: FT UM. 2016.

[24] Tjandra, W. Mesin Mesin Kerja Pelat. Bandung: Divisi Pengembangan Bahan Ajar PPPG Teknologi Bandung. 1992.

[25] Wahyu, K.S., Helmy, P., dan M, Dzulfikar. "Analisis Laju Korosi Dengan Aliran Media Korosi Hcl 10\% Pada Material Baja Astm A36 Dengan Sudut Bending”. Momentum Vol. 15 No: 1.. 2019.

[26] Winarsunu, T. Statistik Dalam Penelitian Psikologi dan Pendidikan. Malang: Universitas Muhammadiyah Malang. 2017.

[27] Yudha, K.A., Irfan, S.A., \& Amiadji. “Analisa Laju Korosi pada Pelat Baja Karbon dengan Variasi Ketebalan Coating”. Jurnal Teknik ITS. 2015.

[28] Yuli, P.A., Tedi, K., Agus, G.E., Jamiluddin, J. "Application of Plants Extracts as Green Corrosion Inhibitors for Steel in Concrete”. Indonesian Journal of Science \& Technology.2018.

[29] Zuchry, M., \& Ramang, M. "Analisis Laju Korosi Dengan Penambahan Pompa Pada Baja Komersil Dalam Media Air Laut”. Jurnal Mekanikal. Vol. 8 No: 2. Dari http://jurnal.untad .ac.id/jurnal/index.php/Mekanikal/article. 2017. 